ENTREPRENEURSHIP AND SUSTAINABILITY ISSUES

ISSN 2345-0282 (online) http://jssidoi.org/jesi/ 2019 Volume 7 Number 1 (September)

http://doi.org/10.9770/jesi.2019.7.1(13)

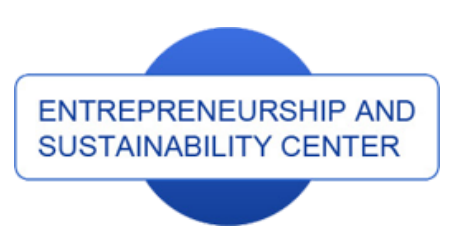

Publisher

http://jssidoi.org/esc/home

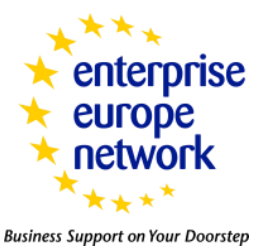

CASPA

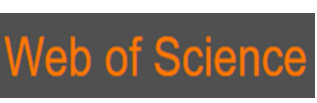

1) Clarivate

\title{
WHY LABOR FORCE PARTICIPATION RATE RISES? NEW EMPIRICAL EVIDENCE FROM INDONESIA
}

\author{
Gatot Sasongko1, Andrian Dolfriandra Huruta² ${ }^{2}$ Kashan Pirzada ${ }^{3}$ \\ ${ }^{1,2}$ Satya Wacana Christian University, Diponegoro 52-60, Salatiga 50711, Indonesia \\ ${ }^{3}$ Tunku Puteri Intan Safinaz School of Accountancy, Universiti Utara Malaysia, Kedah 06100, Malaysia \\ E-mails. ${ }^{1}$ gatot.sasongko@staff.uksw.edu; ${ }^{2}$ andrian.huruta@staff.uksw.edu(corresponing author); \\ 3ashan@uum.edu.my
}

Received 15 March 2019; accepted 28 July 2019; published 30 September

\begin{abstract}
The labor force participation rate in Indonesia has increased during the period from 2008 to 2017 . This paper attempt to investigate the issue, three independent variables encompassing, gross regional domestic product per capita at current prices, male life expectancy, and the number of dependents were considered in this paper, to understand if the selected variables have an impact on the increase in the labor force participation rate in Indonesia. The regional panel data obtained from the Indonesian central bureau of statistics was extracted from the period of 2010 to 2015. The panel data model and the Hausman test were applied to test the hypotheses. The findings indicate that the fixed effect model is suitable for data analysis. The results reveal that gross regional domestic product per capita at current prices positively affect the labor force participation rate while male life expectancy was noted to have a negative effect on the labor force participation rate. Theoretically, a lower income and a higher life expectancy would encourage more people to enter the labor market, but the Indonesian data showed the different and interesting results.
\end{abstract}

Keywords: labor force participation rate; Gross Regional Domestic product per capita; life expectancy; Indonesia

Reference to this paper should be made as follows: Sasongko, G.; Huruta, A.D.; Pirzada, K. 2019. Why labor force participation rate rises? New empirical evidence from Indonesia, Entrepreneurship and Sustainability Issues 7(1): 166-176. http://doi.org/10.9770/jesi.2019.7.1(13)

JEL Classifications: J80, J82, J89

\section{Introduction}

The previous global financial crisis has changed the global economic order of the world. Among the many countries, Indonesia began to feel the financial effect of the crisis during the drastic decline of the economic growth at the end of the year 2008 (SMERU, 2011). The country had recorded an economic growth of above six percent until the third quarter III-2008 and following this, the Indonesian economy began to experience an economic slowdown in the last quarter IV-2008 (Bank of Indonesia, 2009). Fortunately, the Indonesian economy was more resilient to this crisis in relation to its neighboring countries. This is endorsed by the fact that Indonesia 
was still able to record a 4.4 percent growth in the first quarter of I-2009 (SMERU, 2011). During the same period of time, there was no increase in school dropout rate or a decrease in school attendance and the labor force participation rate remained relatively stable (McCulloch \& Grover, 2010) but there was an increase labor force participation rate between 2008 to 2017. This can be seen in Table 1 below.

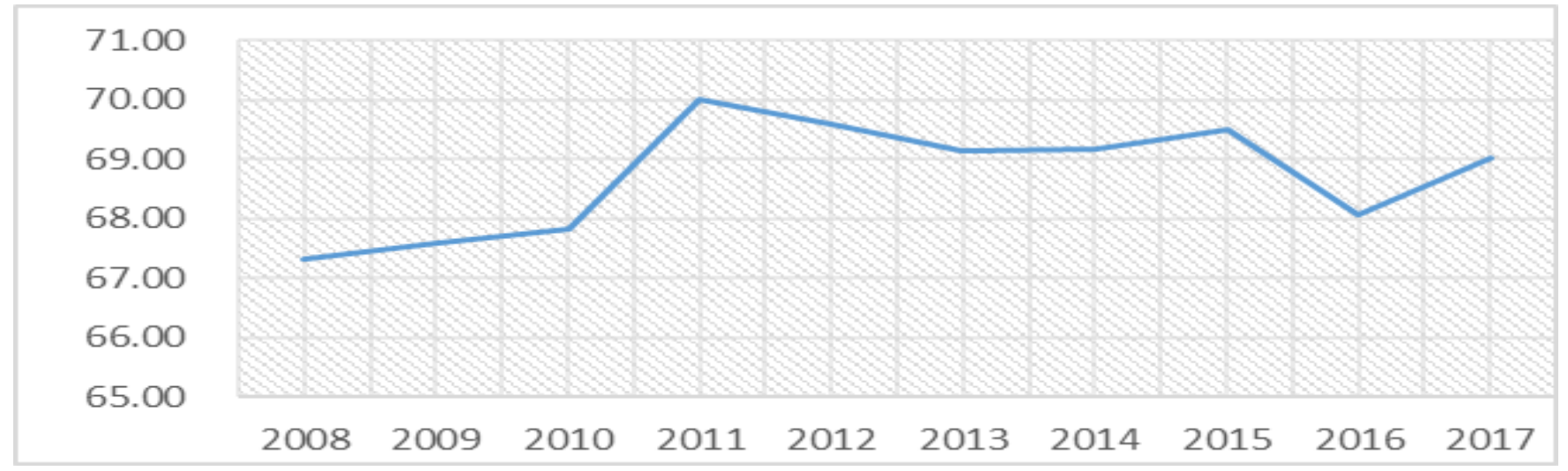

Figure 1. Labor Force Participation Rate Period 2008 - 2017

Source: Central Bureau of Statistics (2018)

Labor force participation rate can be empirically explained. Studies (see Balleer, Gómez-Salvador \& Turunen, 2009; Cai, 2009; Dayığlu \& Kirdar, 2010; Luque, 2013; AaronSon et al., 2014; Reddy, 2016; Blagrave \& Santoro, 2017; Chistobaev et al., 2018; Bernardi 2019) have shown that there are various areas to focus on when examining labor force participation rate. For instance, the textile sector, life cycles, marital status, and the number of children (Dayığlu \& Kirdar, 2010; Luque, 2013), labor market slack (AaronSon et al., 2014), age and cohort effect (Balleer, Gómez-Salvador \& Turunen, 2009), health status (Cai, 2009), ageing (Reddy, 2016; Blagrave \& Santoro, 2017), health expenditures, gross capital formation, mortality rate, secondary school enrolment, life expectancy (Mushtaq, Mohsin, \& Zaman, 2013), structural transformation, education and real wage (Mehrotra \& Parida, 2017), unemployment rate, gross domestic product per capita, fertility rate (Taşseven, Altaş, \& Ün, 2016) and life expectancy (Rechel, Doyle, Grundy \& McKee, 2009). Further to that, women-related issues can also contribute to an increase in labor force participation, for example, female education, sectoral employment share, unemployment rate, wages, marital status (Fatima \& Sultana, 2009), poverty and women workers (Azid, Khan \& Alamasi, 2010), and unemployment rate for females (Özerkek, 2014).

Several studies have empirically shown that many factors affect the labor force participation rate and most seem to come from the household perspective. In that regard, this paper aims to expand on that perspective by attempting to analyze three independent variables namely Gross Regional Domestic Product per capita at current prices, Male Life Expectancy, and the Number of Dependents.

\section{Literature Review}

The Labor-Leisure Choice Theory defines labor force participation as a function of real wage, working, and leisure. This implies that the allocation of working time is a function of the choice between working and leisure, and a function of increased real wage. In contrast, the Added Worker Theory argues that when recession causes husbands to be unemployed, other family members will enter the labor market thereby, producing an "added" number of labor force (Ehrenberg \& Smith, 2012). 


\section{ENTREPRENEURSHIP AND SUSTAINABILITY ISSUES}

ISSN 2345-0282 (online) http://jssidoi.org/jesi/

2019 Volume 7 Number 1 (September)

http://doi.org/10.9770/jesi.2019.7.1(13)

Previous studies have investigated the labor force participation rate of females only, males only or both females and males together. From the female labor force perspective, Fatima and Sultana (2009) found that a higher rate of economic development increases female labor force participation. Women were taking full advantage of the opportunity by increasing their education level and this eventually reflects the U-shape relationship.

By using the non-linear maximum likelihood probability function, Azid, Khan, and Alamasi (2010) found that poverty determines female labor participation. Their results showed that poverty pushes the married women to participate in the labor market. In contrast, Dayığlu and Kırdar's (2010) household survey noted that the geographical shift of the rural population reduces female labor participation. Their findings suggest that rural women tend to migrate and this causes a reduction in female labor force participation rate. This, inevitably causes the part of the agricultural households in villages to decline.

Using the panel data analysis, Özerkek (2014) found a long-term relationship between female unemployment and labor force participation in European countries. The study revealed some aspect of the hidden female unemployment rate. The outcome may be attributed to the Turkish economic structure that was so highly dependent on imported raw materials and which offered low job opportunities. Taşseven, Altaş, and Ün (2016) also used the panel data analysis to identify female labor force participation in OECD countries. They found that unemployment rate, per capita gross domestic product, and fertility rate positively affect female labor force participation rate. The outcome was traced to the significant growth such as increased products exhibited by the observed countries. Deploying the household survey as their method, Mehrotraa and Paridab (2017) note that the structural transformation process of a nation can push a great number of women out of the agricultural sector by thrusting them into the manufacturing sector. Unfortunately, both the agricultural growth mechanism and the capital intensity of the manufacturing sector offer very limited opportunities to women. Consequently, this reduces female labor force participation rate substantially.

From the male labor force perspective, Blagrave and Santoro (2017) found that age is an important factor which can predict the decision to participate in the labor force, particularly for men. The cohort effect and the business cycle can also affect the decision to participate in labor force. Cai (2009) noted that health status can positively influence labor force participation for both men and women. His study also found that labor force participation can negatively affect men's health status but positively affect women's health status.

Using a cohort-based labor force participation model, Balleer, Gómez-Salvador, and Turunen (2009) was able to show that age and cohort can increase labor force participation rate in the Euro area. Using the autoregressive distributed lag, Mushtaq, Mohsin, and Zaman (2013) found that infant mortality rate, gross capital formation, and secondary school participation rate can reduce labor force participation rate, in the long run but health expenditure has a positive effect on the labor force participation rate, in the short run.

From the household perspective, Luque (2013) found that the demand factor (the presence of textile sector) and the supply factor (life cycle, marital status, and number of children) can determine labor force participation rate. However, in aggregate, the demand factor has the strongest effect. By using a probit regression model, Reddy (2016) showed that poor and old people were more likely to participate in the labor force, especially among those in the informal and low-wage sectors. A high proportion of elders who worked freelance or as entrepreneurs had indicated that an absence of pension funds had caused them to join the labor force.

Scholars and policy makers have been debating about the decreased labor force participation rate. Some proposed that weak labor demands suppress labor force participation rate but others proposed that structural forces of a nation, such as an aging population, can contribute to this phenomenon (Aaronson et al., 2014). It appears that the cyclical weakness, as indicated by labor market looseness, is more likely to explain the decrease better than the structural factors. 
Previous studies had exhibited varying results thus the following hypotheses were proposed:

H1: Gross regional domestic product per capita at current prices affects labor force participation rate.

$\mathrm{H} 2$ : Male life expectancy affects labor force participation rate.

H3: The number of dependents affects labor force participation rate.

\section{Reserch Methods}

The panel data extracted for this study consists of two parts: (1) time series data and (2) cross section data. The former comprises the annual data of six years, from 2010 to 2015. The latter comprises data drawn from the Indonesian Central Bureau of Statistics (except for Northern Kalimantan and the Papua provinces).

This study used three independent variables to predict the Indonesian labor force participation rate: Gross Regional Domestic Product per capita at current prices, Male Life Expectancy, and the Number of Dependents. The Gross Regional Domestic Product per capita at the current price was measured by dividing the total gross regional domestic product with the number of population. The number of family members who are dependent on the family heads is the proxy for the Number of Dependents. Lastly, the average remaining life years of a man in certain years was used as the proxy for Male Life Expectancy. The dependent variable, labor force participation rate was measured as the ratio between population above 15 years old who had worked or searched for jobs with the total population that is above 15 years old.

This study uses panel data regression as the estimation technique. First, the best model was selected from between the Fixed Effect Model (FEM) and the Random Effect Model (REM). The Hausman test was then used to determine the model that is most appropriate for the data. The test indicates that the best model is the Fixed Effect Model and this is then used to test the three hypotheses. The calculation is as follows:

$\mathrm{LFPR}_{\mathrm{it}}=\mathrm{a} 0+\mathrm{a} 1 \mathrm{GRDPCap}_{\mathrm{it}}+\mathrm{a} 2 \mathrm{MLE}_{\mathrm{it}}+\mathrm{a} 3 \mathrm{NoD}_{\mathrm{it}}+\mathrm{e}_{\mathrm{it}}$

Where,

LFPR $_{\text {it }} \quad$ : Labor Force Participation Rate of province $i$ in year $t$

GRDPCap $_{\text {it }} \quad$ : Gross Regional Domestic Product per capita at current prices of province $\mathrm{i}$ in year $\mathrm{t}$

MLE $_{\text {it }} \quad:$ Male Life Expectancy in province i year $\mathrm{t}$

$\mathrm{NoD}_{\text {it }} \quad$ : Number of Dependents in province i year $\mathrm{t}$

a $\quad$ : Unobserved time-invariant individual effect

$\mathrm{a}_{1}, \mathrm{a}_{2}, \mathrm{a}_{3} \quad:$ Regression coefficients

$\mathrm{e}_{\mathrm{it}} \quad$ : error term of province $\mathrm{i}$ in year $\mathrm{t}$

This was followed by a subsequent step where the stationary panel data test was run on all the observed variables by using the Levin-Lin Chu (LLC) Unit Root Test method. If all the observed variables are stationary, then only can the FEM model be used to predict the hypothesis.

\section{Results}

In the initial stage, the Hausman Test statistics was compared with the probability value $\alpha=5 \%$ so as to determine the best model. If the probability value is less (more) than $\alpha=5 \%$, then the FEM (REM) would serve as the best model. This can be seen in Table 1 below.

Table 1. Hausman Test

\begin{tabular}{|l|l|l|c|}
\hline \multicolumn{1}{|c|}{ Test Summary } & Chi-Sq. Statistic & Chi-Sq. d.f. & Prob. \\
\hline Cross-section random & 8.403323 & 3 & 0.0384 \\
\hline
\end{tabular}


Table 1 indicates that the best model is the Fixed Effect Model (FEM) because the Hausman Test statistics was 8.403323, with a probability of 0.0348 , less than $\alpha=5 \%$. Before estimating the FEM, the time-series data were observed so as to ensure that the data were stationary and not containing any unit root. This can be seen in Table 2 below.

Table 2. Unit Root Test

\begin{tabular}{|l|l|l|l|}
\hline Parameter & \multicolumn{1}{|c|}{ Hypotheses } & P-Value & Conclusion \\
\hline \multirow{2}{*}{ LFPR } & Ho: Panels contain unit root & 0.0000 & I (0) \\
\cline { 2 - 2 } & Ha: Panels are stationary & & \\
\hline \multirow{2}{*}{ GRDPCap } & Ho: Panels contain unit root & 0.0000 & I (0) \\
\cline { 2 - 2 } & Ha: Panels are stationary & & \\
\hline MLE & Ho: Panels contain unit root & 0.0000 & I (0) \\
\cline { 2 - 2 } & Ha: Panels are stationary & & \\
\hline NoD & Ho: Panels contain unit root & 0.0000 & I (0) \\
\cline { 2 - 2 } & Ha: Panels are stationary & & \\
\hline
\end{tabular}

Table 2 indicates that the observed variables are stationary on the level integration degree $\left(\mathrm{I}_{0}\right)$ with a confidence level of $95 \%$. This suggests that the data can be used for further analysis. Moreover, the panel dta regression results can be seen in Table 3 .

Table 3. Fixed Effect Model

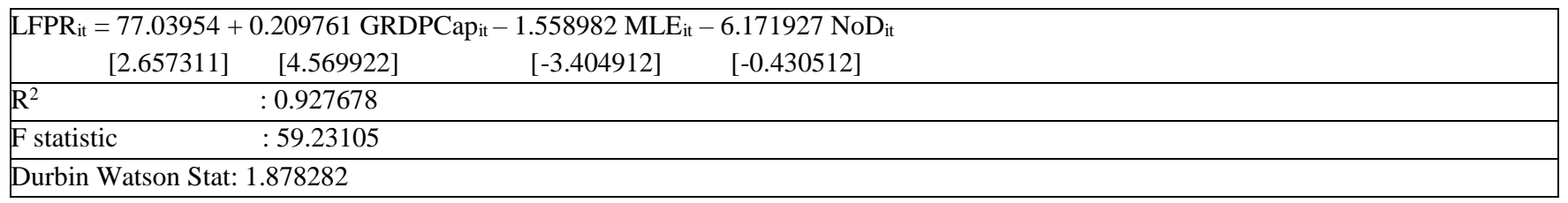

Table 3 indicates that the Gross Regional Domestic Product per capita at current prices positively affects the labor force participation rate. The results also showed that Male Life Expectancy has a negative influence on labor force participation rate. However, the number of dependents exhibited no significant effect on labor force participation rate.

\section{Discussions}

\subsection{Gross regional domestic product per capita at current prices affects labor force participation rate}

The estimation results gained through the Fixed Effect Model support the first hypothesis (H1). In the Indonesian context, increased income per capita at current prices generally increases labor force participation rate. The income per capita at current prices was used as the independent variable because in general, the Indonesian population spends more than sixty percent (60\%) of their income on their primary needs namely, food and beverages, clothes, housing, health, and education. Expenditures for the primary needs were subject to inflation less. Table 4 shows the Gross Domestic Product at current prices, based on expenditure categories. 
Table 4. GDP at Current Prices based on Expenditure Categories (\%) 2010 - 2016

\begin{tabular}{|c|l|l|l|l|l|l|l|l|}
\hline No & Expenditure Categories & $\mathbf{2 0 1 0}$ & $\mathbf{2 0 1 1}$ & $\mathbf{2 0 1 2}$ & $\mathbf{2 0 1 3}$ & $\mathbf{2 0 1 4}$ & $\mathbf{2 0 1 5}$ & $\mathbf{2 0 1 6}$ \\
\hline 1 & Food and Beverage, non-Restaurant & 38.5 & 38.5 & 38.9 & 38.5 & 38.0 & 38.5 & 39.2 \\
\hline 2 & Clothes, Footwear and Their Maintenance Services & 4.1 & 4.1 & 3.9 & 3.8 & 3.7 & 3.7 & 3.6 \\
\hline 3 & Housing and Household Appliances & 13.6 & 13.4 & 13.4 & 13.3 & 13.1 & 13.1 & 12.8 \\
\hline 4 & Health and Education & 6.7 & 6.8 & 6.9 & 6.8 & 6.7 & 6.7 & 6.7 \\
\hline 5 & Transportation and Communication & 23.6 & 23.3 & 22.8 & 23.4 & 24.0 & 23.3 & 22.8 \\
\hline 6 & Restaurant and Hotel & 8.9 & 9.0 & 9.3 & 9.4 & 9.6 & 9.8 & 9.9 \\
\hline 7 & Others & 4.5 & 4.8 & 4.9 & 4.8 & 4.8 & 4.9 & 4.9 \\
\hline & Total Household Consumption Expenditures & 100 & 100 & 100 & 100 & 100 & 100 & 100 \\
\hline
\end{tabular}

Besides the above, the Time Allocation theory can also be used to explain the effect of the income per capita at current prices on labor force participation rate. This theory assumes that workers either opt for working or for leisure. At certain income levels, these workers will decide on how to allocate their time into working or leisure. It appears that low-income individuals were more likely to have insufficient income to meet their needs thus it encourages family members who were previously not in the labor force to join the labor market (added worker theory). This can be seen in Figure 2 below.

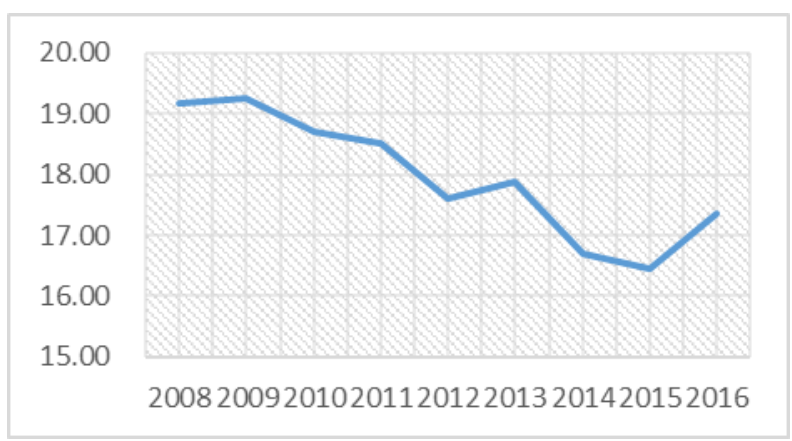

Figure 2. Population of $20-24$ Years Old Who Look After Households Source: Central Bureau of Statistics (2018d)

Figure 2 indicates that the number of those aged $20-24$ years old who are not in the labor force (looking after households) had declined sharply during 2008-2016. These figures support the added worker theory which argues that low income encourages those previously not in the labor force, due to taking care of their households, to participate in the labor market so as to help their households meet their needs.

The Income per capita figure illustrates the ratio between the GDP and the number of population. The previous part of this paper had explained that the effect of income per capita on labor force participation depends on the income level. This implies that income distribution affects labor force participation rate. In the Indonesian context, the rural population exhibits a different Gini ratio pattern than the urban population. More specifically, the Gini ratio of the urban areas tends to be higher than that of the rural areas which tends to remain relatively constant. This can be seen in Figure 3 below. 


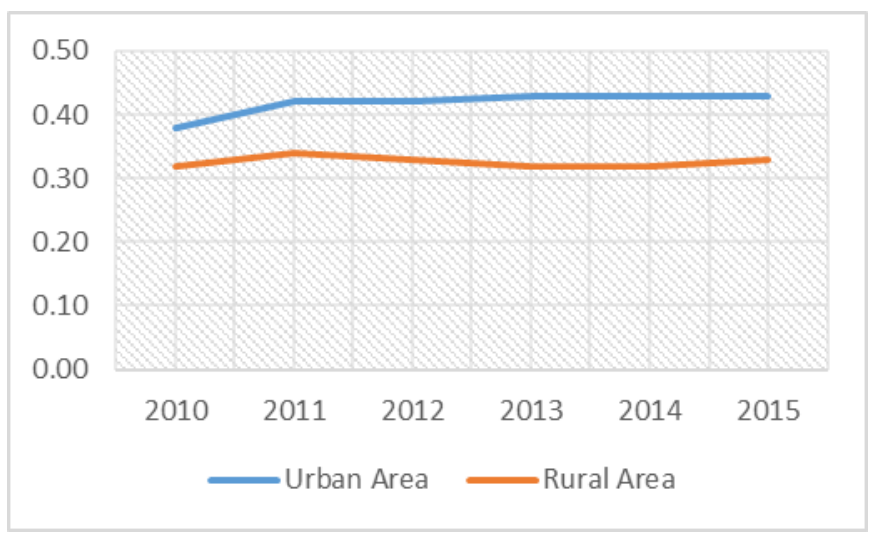

Figure 3. Comparison of Urban and Rural Gini Ratio Source: Central Bureau of Statistics (2018a)

Figure 3 indicates that most of the Indonesian population live in the rural areas. The fact that the urban areas have a higher Gini index indicates that the largest proportion of the Indonesian population contributes to a smaller portion of the total GDP. In other words, the largest proportion of the Indonesian population are those from the rural areas with low income. In their study, Hubacek, Guan, and Barua (2007) argued that the economic success of several Asian developing countries had improved the quality of life for their population. It appears that majority of the population in these countries have undergone a transition, moving from poverty to sufficient fulfillment of their basic needs (e.g. foods, clothes). However, these people are not satisfied with only fulfilling their basic needs; they also wish to have a better life quality, such as highly nutritious food, better health care, more life comforts, and other life desires. Consequently, the relationship between the Gross Regional Domestic Product per capita at current prices and the labor force participation rate is positive.

\subsection{Male life expectancy affects labor force participation rate}

The test was applied by using the fixed effect model and the outcome supports the second hypothesis (H2) of this study. The fact that the Labor Force Participation Rate of the population aged 20-59 years old and those above 60 years old had increased. This suggests that a higher life expectancy increases labor force participation rate for these two age groups.

In the meantime, the Indonesian paternalistic culture which requires men to serve as family heads suggest that men enter the labor force. This factor confirms the current findings as the Indonesian quality of public health had equally increased (Ministry of Health, 2015). Central Bureau of Statistics (2018e) had reported that during the period of 2009 to 2015 , the percentage of the population who have health complaints had decreased from $33.68 \%$ to $30.35 \%$. This condition makes the population who are above 60 years old still able to participate in the labor market.

Relevant to this, Mustaq, Mohsin, and Zaman (2013) further proposed that well-managed health expenditure increases life expectancy at birth. Likewise, this will eventually increase labor force participation rate because people will have more years to enter the labor market.

In the Indonesian context, it appears that the Labor Force Participation Rate of the young population (those who are 15-19 years old) tends to decline. This suggests that most of the young population prefer to continue with their studies rather than enter the labor market. It also implies the success of the compulsory education program in Indonesia. This can be seen in Figure 4 below. 


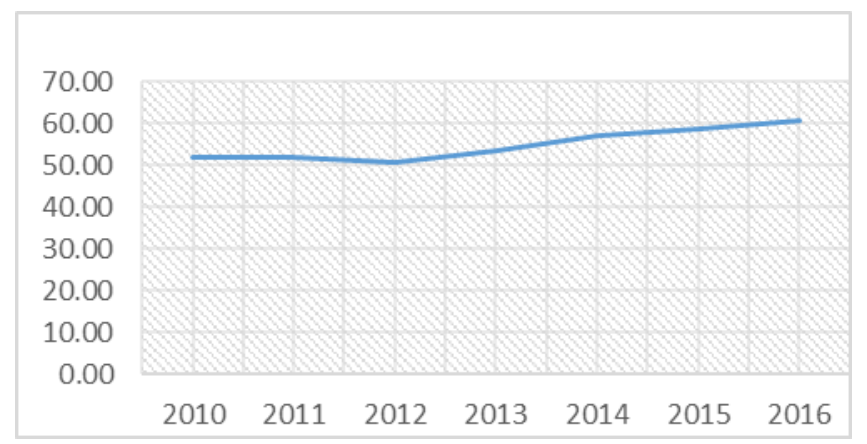

Figure 4. Population of 15-19 Years Old Who Continue Their Studies Source: Central Bureau of Statistics (2018c)

In relation to these findings, Hipple (2016) had proposed that from 2000 to 2015, the younger population exhibit showed a decline in the labor force participation. The adolescents exhibited the largest decline in the labor force participation rate and this is possibly due to the increased school enrollment rate which implies that they prefer to continue their studies than to participate in the labor force. This can be seen in Figure 5 below.

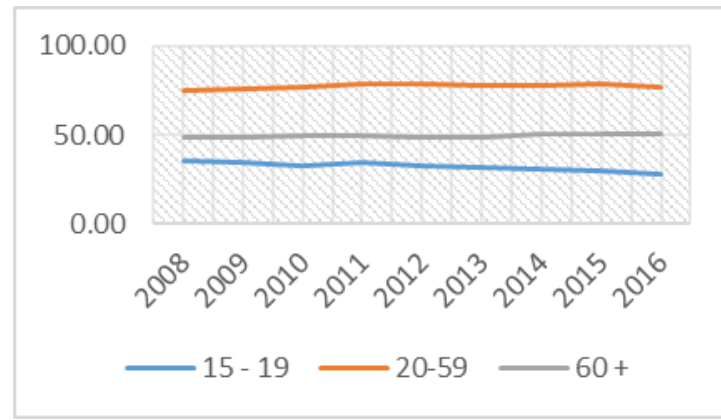

Figure 5. Labor Force Participation Rate by Age Group Source: Central Bureau of Statistics (2018d)

Figure 5 indicates when the LFPR of the population aged 15-19 years old decreases because of the increased intention to continue with their studies, the LFPR of the population aged 20-59 years old and those above 60 years old increases. In sum, male life expectancy has a negative effect on labor force participation rate.

\subsection{Number of dependents affects labor force participation rate}

Using the fixed effect model, the test did not support the third hypothesis (H3). However, Mustaq, Mohsin, and Zaman (2013) stated that the number of dependents is a great impediment for growth and development. They proposed that governments reduce the number of dependents by providing old-age allowance to older workers and free educational and health facilities to the children.

\section{Conclusions}

This paper contributes to the empirical literature on the fact that low-income households constitute the largest proportion of the Indonesian population explains the positive relationship between the Gross Regional Domestic Product per capita at current prices and the labor force participation rate. However, Male Life Expectancy is negatively related to labor force participation because of the success of the compulsory education programs 


\section{ENTREPRENEURSHIP AND SUSTAINABILITY ISSUES}

ISSN 2345-0282 (online) http://jssidoi.org/jesi/ 2019 Volume 7 Number 1 (September) http://doi.org/10.9770/jesi.2019.7.1(13)

implemented by the government. Consequently, it is necessary for the Indonesian government to focus more on the low-income population and to simultaneously, increase the quality of public health.

While the unemployment rate has declined in recent years, labor force participation has also been declining, perhaps suggesting that unemployment is not as reliable an indicator of macroeconomic performance as it may have been in the past, but unemployment rate has positive relationship with female labor force participation established in few researches. The rise in labor force participation is often attributed in part to the maturing of the Baby Boom generation, as well as to the increase in the number of women in the workforce. The decline has often been attributed to the aging of the Indonesian labor force. A satisfactory model has to account for the rise and fall over many decades. The literature is not completely satisfactory, however, household decision making inside economic models. This would allow us to better understand what motivates or deters labor force participation.

\section{References}

Aaronson, S.; Cajner, T.; Fallick, B.; Galbis-Reig, F.; Smith, C.; \& Wascher, W. (2014). Labor force participation: recent developments and future prospects. Brookings Papers on Economic Activity, 42(2), 197-275. Retrieved from https://www.brookings.edu/wpcontent/uploads/2016/07/Fall2014BPEA_Aaronson_et_al.pdf

Azid, T.; Ejaz Ali Khan, R.; \& Alamasi, A. M. (2010). Labor force participation of married women in Punjab (Pakistan). International Journal of Social Economics, 37(8), 592-612. Retrieved from https://doi.org/10.1108/03068291011060643

Bank of Indonesia. (2009). Laporan Tahunan Perekonomian. Retrieved from https://www.bi.go.id/id/publikasi/laporantahunan/perekonomian/Default.aspx

Balleer, A.; Gómez-Salvador, R.; \& Turunen, J. (2009). Labour Force Participation in the Euro Area: A Cohort Based Analysis. In Working Papers Series (No. 1049). Retrieved from https://www.ecb.europa.eu//pub/pdf/scpwps/ecbwp1049.pdf

Bernardi, A. (2019). The capability approach and organizational climate as tools to study occupational health and safety. Insights into Regional Development, 1(2), 155-169. https://doi.org/10.9770/ird.2019.1.2(6)

Blagrave, P.; \& Santoro, M. (2017). Labor Force Participation in Chile: Recent Trends, Drivers, and Prospects. In IMF Working Paper (No. 17/54). Retrieved from https://www.imf.org/en/Publications/WP/Issues/2017/03/13/Labor-Force-Participation-in-Chile-Recent$\underline{\text { Trends-Drivers-and-Prospects-44741 }}$

Cai, L. (2010). The relationship between health and labour force participation: Evidence from a panel data simultaneous equation model. Labour Economics, 17(1), 77-90. Retrieved from https://doi.org/10.1016/j.labeco.2009.04.001

Central Bureau of Statistics. (2018a). Kemiskinan dan Ketimpangan. Retrieved from https://www.bps.go.id/subject/23/kemiskinan-danketimpangan.html\#subjekViewTab6

Central Bureau of Statistics. (2018b). PDB Triwulanan Atas Dasar Harga Berlaku Menurut Pengeluaran (Miliar Rupiah), $2014-2018$. Retrieved from Badan Pusat Statistik website: https://www.bps.go.id/dynamictable/2015/08/06/834/-seri-2010-pdb-triwulanan-atas-dasarharga-berlaku-menurut-pengeluaran-miliar-rupiah-2014-2018-.html

Central Bureau of Statistics. (2018c). Pendidikan. Retrieved from https://www.bps.go.id/subject/28/pendidikan.html\#subjekViewTab6

Central Bureau of Statistics. (2018d). Penduduk Berumur 15 Tahun Ke Atas Menurut Golongan Umur dan Jenis Kegiatan Selama Seminggu yang Lalu, 2008 - 2018. Retrieved from https://www.bps.go.id/statictable/2016/04/04/1904/penduduk-berumur-15-tahun-keatas-menurut-golongan-umur-dan-jenis-kegiatan-selama-seminggu-yang-lalu-2008---2018.html

Central Bureau of Statistics. (2018e). Persentase Penduduk yang Mempunyai Keluhan Kesehatan Selama Sebulan Terakhir menurut Provinsi, 2000-2017. Retrieved from https://www.bps.go.id/dynamictable/2015/09/19/921/persentase-penduduk-yang-mempunyaikeluhan-kesehatan-selama-sebulan-terakhir-menurut-provinsi-2000-2017.html 


\section{ENTREPRENEURSHIP AND SUSTAINABILITY ISSUES}

ISSN 2345-0282 (online) http://jssidoi.org/jesi/ 2019 Volume 7 Number 1 (September)

http://doi.org/10.9770/jesi.2019.7.1(13)

Chistobaev, A.I.; Semenova, A.Z.; Grudtsyn, N.A. (2018). Dynamics and strategic directions of public health preservation in Russian Federation. Entrepreneurship and Sustainability Issues, 6(3), 1180-1192. . http://doi.org/10.9770/jesi.2019.6.3(23)

Dayığlu, M.; \& Kırdar, M. G. (2010). Determinants of and trends in labor force participation of women in Turkey. In Working Paper (No. 5). Retrieved from https://pdfs.semanticscholar.org/be5f/23b7c993fdd6a564947557a02a8a85da4ab1.pdf

Ehrenberg, R. G.; \& Smith, R. S. (2012). Modern labor economics: Theory and public policy (11th ed.). Boston: Pearson Education. http://fac.ksu.edu.sa/sites/default/files/Modern_labor_economics_theory_and_public_policy_0.pdf

Fatima, A.; \& Sultana, H. (2009). Tracing out the U-shape relationship between female labor force participation rate and economic development for Pakistan. International Journal of Social Economics, 36(1/2), 182-198. Retrieved from https://doi.org/10.1108/03068290910921253

Hubacek, K.; Guan, D.; \& Barua, A. (2007). Changing lifestyles and consumption patterns in developing countries: A scenario analysis for China and India. Futures, 39(9), 1084-1096. Retrieved from https://core.ac.uk/download/pdf/51098.pdf

Luque, C. C. (2014). La tasa de actividad femenina a mediados del siglo XIX en Andalucía: el caso de Antequera. Investigaciones de Historia Económica-Economic History Research, 10(3), 191-201. Retrieved https://www.researchgate.net/profile/Maria Nayra Rodriguez Rodriguez/publication/325570010 La ensenanza de literatura a traves d e_las_infografias/links/5b167bef4585151f91fb8a3f/La-ensenanza-de-literatura-a-traves-de-las-infografias.pdf

McCulloch, N.; \& Grover, A. (2010). Estimating the national impact of the financial crisis in Indonesia by combining a rapid qualitative study with nationally representative surveys. In IDS Working Papers (No. 346). Retrieved from https://assets.publishing.service.gov.uk/media/57a08b2a40f0b649740009e6/IndonesiaFinancialCrisispaperv7ST_1_.pdf

Mehrotra, S.; \& Parida, J. K. (2017). Why is the Labour Force Participation of Women Declining in India? World Development, 98, 360380. Retrieved from https://doi.org/10.1016/j.worlddev.2017.05.003

Mushtaq, A.; Mohsin, A.; \& Zaman, K. (2013). Effects of health on changing labor force participation in Pakistan. Springer Plus, 2(1), 610. Retrieved from https://doi.org/10.1186/2193-1801-2-610

Özerkek, Y. (2014). Paid employment and growth in Turkey (1988-2013). Journal of Economic and Administrative Sciences, 36(1), 215227.

Reddy, A. B. (2016). Labour force participation of elderly in India: patterns and determinants. International Journal of Social Economics, 43(5), 502-516. Retrieved from https://doi.org/10.1108/IJSE-11-2014-0221

SMERU. (2011). What is the Impact of the Global Financial Crisis for Workers: Flexibility and. Protection: A Case Study of the Utilization of Subcontract Workforce in Bekasi Indonesia. The SMERU Research Institute. Retrieved from http://smeru.or.id/en/report-types/research$\underline{\text { report }}$

Taşseven, Ö.; Altaş, D; \& Turgut, Ü. N. (2016). The determinants of female labor force participation for OECD countries. Uluslararası Ekonomik Araştırmalar Dergisi, 2(2), 27-38. Retrieved from http://hdl.handle.net/11376/2660

Ministry of Health. (2015). Rencana Strategis Kementerian Kesehatan Tahun 2015 - $2019 . \quad$ Retrieved from http://www.depkes.go.id/resources/download/info-publik/Renstra-2015.pdf 


\section{ENTREPRENEURSHIP AND SUSTAINABILITY ISSUES}

ISSN 2345-0282 (online) http://jssidoi.org/jesi/ 2019 Volume 7 Number 1 (September)

http://doi.org/10.9770/jesi.2019.7.1(13)

Gatot SASONGKO, Dr. is an associated professor and the head of economics department at the Faculty of Economics and Business of Satya Wacana Christian University. His fields of expertise are labor economics, quantative research and macroeconomic policy. His publications have appeared at various national journals in Indonesia and international journals.

ORCID ID: https://orcid.org/0000-0003-0381-9348

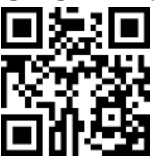

Andrian Dolfriandra HURUTA, M.Si. is a lecturer at the Faculty of Economics and Business of Satya Wacana Christian University. His fields of expertise are macroeconomic policy and applied econometrics. His publications have appeared at various national journals in Indonesia and international journals.

ORCID ID: https://orcid.org/0000-0001-7676-5294

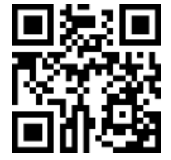

Kashan PIRZADA, Dr. is a Senior lecturer in Tunku Puteri Intan Safinaz School of Accountancy, Universiti Utara Malaysia, Malaysia. He has been a lead guest editor for Elsevier Procedia of Social and Behavioural Sciences, Pertanika of Social Sciences and Humanities, and International Journal of Economics and Management.His publications have appeared in various International academic journals, such as Elsevier Journal of Social and Behavioural Sciences, British Accounting and Finance; Polish Journal of Management Studies; Pertanika Journal of Social Sciences and Humanities, and International Journal of Economics and Management.

ORCID ID: https://orcid.org/0000-0003-1186-0631

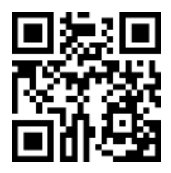

Copyright (C) 2019 by author(s) and VsI Entrepreneurship and Sustainability Center

This work is licensed under the Creative Commons Attribution International License (CC BY).

http://creativecommons.org/licenses/by/4.0/

cC) (i) Open Access 